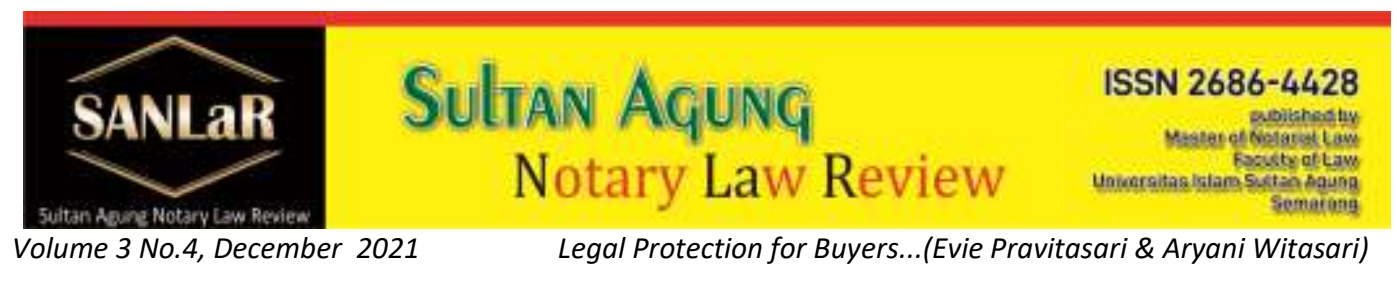

\title{
Legal Protection for Buyers against the Understanding of Home Ownership Loans
}

\author{
Evie Pravitasari ${ }^{*}$ and Aryani Witasari ${ }^{* *}$ \\ ${ }^{*}$ Faculty of Law, Universitas Islam Sultan Agung (UNISSULA) Semarang, E-mail: \\ eviepravittasari@gmail.com
}

$\left.{ }^{* *}\right)$ Faculty of Law, Universitas Islam Sultan Agung (UNISSULA) Semarang, E-mail: aryani@unissula.ac.id

\begin{abstract}
Subsidized Home Ownership Loans are loans intended for lower-middle income communities in order to meet housing needs or repair houses that they already own. KPR is a credit facility provided by the Bank as a creditor to consumers (buyers) as debtors which are used to purchase land and houses on it. The approach used in this study is a normative juridical approach. The results of this study are: 1) Legal protection for buyers in cases of buying and selling houses and land under the hands can be obtained by submitting an application for determination to the local district court to ratify the buying and selling process, 2) The validity of buying and selling which aims to take over ownership credit house under the hand is not binding on third parties. In connection with this, according to law the legal owner of the land and building is the owner of the first party so that the transfer of rights must go through/obtain the approval of the first party. This makes it difficult in the future, especially if the owner's whereabouts are known.
\end{abstract}

Keywords: Credits; House; Ownership; Takeovers; Underhand.

\section{Introduction}

The house is one of the basic human needs as regulated in the 1945 Constitution Article $28 \mathrm{~h}$ number 1 (Second Amendment of 2000). The role of the government in meeting the community's need for housing is very much needed in providing funds and providing initiatives in housing development efforts. The presence of the Home Ownership Credit system is very much needed by people whose economic income is in the small and medium levels. Credit institutions in Indonesia have a function as a means of supporting the success of development. The role of banks in financing will be even greater, this is because the funds needed for development come from or are collected from the community 
through banking, which are then channeled back to the community in the form of providing credit in a more productive direction.

Housing problems are a big problem for urban areas. The high cost of building a house, and the difficulty of finding appropriate land in urban areas, encourage developers and the government to provide an alternative in the form of Home Ownership Credit (KPR). Home Ownership Credit (KPR) is included in consumer credit, because credit is given to debtors which is usually used to buy a house as a place to live or be inhabited which is one of the basic human needs. ${ }^{1}$ These efforts are directed at providing convenience for the community to own their own homes, and to support good urban planning. Owning a house is one of the factors that support the prosperity of a country, and it is the right of every citizen to fulfill the need for a place to live. Owning your own home is now no longer a difficult thing, because there is a home ownership credit facility provided by the banking community which is commonly called a Home Ownership Credit (KPR). ${ }^{2}$

Prior to the maturity date of the Defendant's loan repayment period, the house and land were sold privately by the Defendant to the Plaintiff on October 9, 1990 with an agreed price of IDR 1,079,000, - (One million seventy-nine thousand rupiah). The Plaintiff has purchased the house and land, the Plaintiff bears what is the Defendant's obligation, namely to pay the installments of the Home Ownership Credit up to the full amount to the Co-Defendant, but when the Building Rihts Use(HGB) certificate will be reversed to be in the name of the Plaintiff, but by The Defendant was not submitted without the presence of the Defendant, and the Plaintiff has tried to find the Defendant everywhere to be invited to follow up the sale and purchase of the house and land to no avail. There is no other way for the Plaintiff than to file a lawsuit against the Defendant. The house and land have been inhabited by the Plaintiff and his family since the sale and purchase with the Defendant was carried out on October 9, 1990 until now.

\section{Research Methods}

Approach used in this study is a normative juridical approach. This research method is a legal research method of literature where the method or method used in legal research is carried out by examining existing library materials. Normative legal provisions (in abstracto) on certain legal events (in concreto).

\footnotetext{
${ }^{1}$ Yusuf, Rifki. (2018). Peran Notaris Dalam Penggunaan Akta SKMHT Yang Tidak Diikuti APHT Terhadap Debitor Wanprestasi Terkait Pemberian Fasilitas Kredit Pemilikan Rumah Subsidi (Studi Kasus di Bank Tabungan Negara Pekalongan), Jurnal Akta, Vol 5, (No. 1)

${ }^{2}$ Sapi'i. (2016). Pemilihan Pembiayaan KPR (Kredit Pemilikan Rumah) Dengan Akad Murabahah (Studi Kasus Di Bank Muamalat Tbk Cabang Pembantu Samarinda Seberang), Al-Tijary Jurnal Ekonomi dan Bisnis Islam, Vol. 2 (No. 1)
} 


\section{Results and Discussion}

1. Legal Protection for Buyers Against Buying and Selling Takeover Home Ownership Loans Done Under Hand

Housing purchased through KPR facilities, buying and selling of houses and land for KPR-BTN by their owners before the credit period ends, has become a "common thing" to be done by the community, even from various newspapers published by the Capital City of Jakarta, you can almost always find advertisements containing offer to do "over credit" KPR. As a legal act that exists in the midst of society, of course there are factors behind the occurrence of buying and selling houses and land for KPR-BTN under the hands. Buying and selling of land and houses under the ownership of KPR-BTN by the owner during the current credit period is influenced by several factors as follows:

1. Homeowners (BTN debtors) are no longer able to carry out their obligations to pay KPR-BTN installments in accordance with the credit agreement because they no longer have a permanent job or are subject to Termination of Employment (PHK) so that financially they no longer have the ability to continue KPR. This inability can also occur if the home owner (BTN debtor) who is an entrepreneur by profession and then there is a business setback and/or has a large amount of debt, so that it greatly affects the level of ability to pay mortgages.

2. Homeowners (BTN debtors) are experiencing other financial difficulties.

3. Homeowners (BTN debtors) urgently need some money for various needs so they sell BTN KPR units.

4. Homeowners (BTN debtors) do not have good intentions to fulfill their obligations, namely paying mortgages according to the agreement.

5. The owner of the house (BTN debtor) changes residence (changes domicile).

6. The public's lack of understanding of the law, especially regarding the procedures and or process of transferring ownership of houses and land for KPR-BTN in accordance with applicable legal provisions, BTN provisions and the terms and conditions for granting KPR-BTN which have been stated in the KPR-BTN Agreement. ${ }^{3}$

Meanwhile, from interviews that the author conducted with 5 (five) people who had bought and sold houses and land under their hands, it can be found the factors that caused the buying and selling:

1. Homeowners (BTN debtors) are no longer financially able to pay installments on KPR-BTN credit mainly due to the economy.

\footnotetext{
${ }^{3}$ Interview with Bayu Sulistyo, as the Head of the Semarang City BTN Branch on Semarang, July 6, 2021.
} 
2. The process and procedure for transferring ownership of houses and land to KPR-BTN, if done through BTN, is officially considered to require many requirements, takes a long time and is high in costs. Meanwhile, the owner needs some money from the sale of the house and land in a relatively short time. Considering that buying and selling houses and land is usually done because of an urgent situation.

3. Buying and selling houses and land under KPR-BTN are carried out for practical, efficient and inexpensive reasons from the cost side.

4. Lack of understanding of the procedures and or process of transferring ownership of the KPR-BTN house and land in accordance with applicable legal provisions, BTN provisions and the terms and conditions for granting KPR-BTN which have been stated in the KPR-BTN Agreement.

The above factors according to the author, there are 3 (factors) important behind the occurrence of buying and selling of KPRBTN houses under the hands, namely: First, the factor of economic need, where old debtors desperately need funds quickly and or are no longer able to pay installments credit. So it is necessary to sell the house unit immediately, even if it is under the hand in order to avoid a convoluted process. Second, the procedural transfer of ownership through BTN takes a long time and costs. Third, from a legal perspective, there is a lack of legal understanding of the community regarding the legal aspects of buying and selling houses. There is a perception that buying and selling and/or over credit carried out underhand is legally strong enough.

According to the owner of KPR-BTN (who has transferred KPRBTN under the hands by means of buying and selling), buying and selling of houses and land for KPR-BTN under the hands is seen as more practical and efficient because it does not require a long time and a complicated process. In this case, if the prospective buyer has agreed to a predetermined price, the transaction will be carried out by making private letters based on the trust of each party to the other. In the process of over credit (credit takeover) the prospective buyer pays a sum of money to the owner of the BTN KPR and henceforth the buyer will continue the remaining credit period which is still running or in other words the buyer will continue the obligation to pay the credit to BTN. ${ }^{4}$

According to the author, besides the process of over-credit through BTN directly by means of "Debtor Transfer" mentioned above, there is another process that is quite safe to do, although it is not as perfect as direct debtor transfer, namely the transfer of rights to land and buildings using a notarial deed by making Land and Building Sale and Purchase Binding Agreement, if the payment is made in full by the buyer and/or in stages over a not too long period of time. After the process of paying off the KPR BTN is complete and the certificate has been

${ }^{4}$ Interview with Y. Sugianto, as the owner of KPR-BTN in Semarang on Semarang, July 6, 2021. 
secured and received by the owner of the old KPR BTN, it is immediately followed by the making of the Deed of Sale and Purchase of Land and Buildings before the PPAT.

If the buyer only pays a certain amount of money to the owner of the old BTN KPR home, and then the buyer will continue the installments or obligations of the old debtor, then the process of transferring the debtor through BTN is officially the safest alternative to do. In practice, based on the author's observations and interviews with KPR BTN owners who have done over credit and home buyers, it can be seen that the parties only made an underhand agreement regarding the sale and purchase of the house and land, and then the parties made a power of attorney and power of attorney. to take a land certificate at BTN when the KPR BTN installment period is complete and paid off. According to the author, this method is a form of legal smuggling and still has no legal certainty. ${ }^{5}$

From the results of the research conducted, it is known that in a credit agreement, the debtor is considered to have committed a default if he does not perform according to the agreement. The debtor's negligence in fulfilling his obligations is very detrimental to the bank as the creditor. The condition of the debtor not being able to pay off his credit in accordance with the agreement can be called bad credit. The bad credit itself can be caused by one or several factors that must be recognized early by the bank. And the bank must always monitor the ability and development of the debtor.

In banking practice, in addition to default based on the ability of the debtor to pay installments or repay the loan as mentioned above, default is also based on a violation of the provisions set by the bank relating to the provision of credit. Based on the results of the research, it is known that there are 15 bad loans with mortgage guarantees from 226 Home Ownership Credit (KPR) agreements guaranteed with mortgages during the period December 2007 or 1 (one) financial year.

If after the bank has tried to go through preventive efforts but finally the credit that has been issued becomes non-performing credit, then the bank will use repressive measures. The first repressive measures to be taken are credit rescue efforts. Bank's efforts to save credit are bank efforts to re-launch loans that have been classified as "non-current", "doubtful" or even classified as "bad credit" to return to "current credit" so that debtors again have the ability to pay back to the creditor bank all debts are accompanied by fees and interest.

\footnotetext{
${ }^{5}$ Interview with Susilowati, as PPAT/Notary Semarang City on Semarang, July 10, 2021.
} 
If it turns out that credit rescue efforts cannot be carried out or even though they have been carried out but do not bring results, the bank will take credit collection efforts. Furthermore, if according to the bank's consideration, it is impossible to save the non-performing credit to become smooth again through rescue efforts and eventually the credit concerned becomes bad debt, then the bank will take steps to settle or collect the credit.

What is meant by the settlement of bad loans or collection of bad loans is the bank's efforts to recover payments from debtors for bank loans that have become bad. To settle or collect bad loans, banks can take the following measures:

a) Execution of Grosse Deed of Debt Recognition (House Ownership Loan agreement);

b) Execution of Guaranteed Goods.

Actually, the Bank as the holder of the guarantee can cancel the sale and purchase of a mortgage house by the old debtor which is carried out under the hands. Sales and purchase letters made under the hands in the sense that they are not through a General Official (PPAT) cannot be used as a means of turning the name of a certificate from an old debtor to a new debtor. Because a private sale and purchase deed cannot be used as a legal basis for a certificate, it can be said that the sale and purchase of land has never happened. ${ }^{6}$

According to the author, BTN needs to conduct socialization and dissemination of adequate information regarding the debtor transfer process in accordance with BTN provisions, so that it can be understood by the wider community. BTn also needs to create a more efficient debtor transfer system, so that new prospective debtors are not burdened by high costs and a long time. This policy is important to overcome and prevent the transfer of KPR BTN under the hands. According to the author, BTN also needs to continuously monitor the condition of the debtor and the object of the BTN KPR (house), so that it can anticipate deviations from the debtor. If there has been a transfer of land rights under the hands. The alternative method of settlement that best fulfills the sense of justice for all parties is that the buyer asks for the legalization of the buying and selling process under the hands of the local district court. Meanwhile, according to the author, execution efforts should be used as a last resort

2. The Legitimacy of Buying and Selling Aims to Take Over Home Ownership Loans Under Hand

\footnotetext{
${ }^{6}$ Turkhon Maulawy, interview, Head of Semarang City BTN Branch, (Semarang, August 14, 2021).
} 
Selling a mortgage house under the hands of a debtor who has not paid off his debt is an act against the law because the mortgage house is a debt guarantee object for the debtor to the bank, so the bank can demand the debtor to provide compensation and immediately pay off the entire remaining debt. This sale does not eliminate the debtor's obligation to pay off the debt.

The bank, as the holder of the guarantee, can cancel the sale and purchase of a mortgage house by the old debtor which is carried out under the hands. Purchase and sale letters made under the hands in the sense that they are not through the Land Deed Making Officer (PPAT) cannot be used as a means of changing the name of the certificate from the old debtor to the new debtor. Because the deed of sale and purchase under the hand cannot be used as a legal basis behind the name of the certificate, it can be said that the sale and purchase has never occurred. If the credit has not been repaid, then the sale of the mortgage house by the old debtor is carried out under the hands without the permission of the bank, legally the bank can cancel through the District Court for the sale, so that the sale becomes invalid.

A certified Home Ownership Loan Transfer Agreement that is still enforced without the bank's approval creates a law between the parties that make it. The legal relationship contains reciprocal obligations and rights between the parties. If both parties do not fulfill the legal obligations set out in the agreement, it will not cause problems, because the legal obligations are essentially only at the stage of being accepted to be implemented. But if one of the parties has carried out a legal obligation, then there is a problem, namely a default which results in not achieving the goal. In this case, sanctions appear to force the party who is in default to fulfill obligations. ${ }^{7}$ Article 584 of the Civil Code states that the method of obtaining property rights is because the surrender based on a civil event to transfer property rights is carried out by people who have the right to act freely on objects. This provision implies that no one has more rights to others than the rights he has. ${ }^{8}$

If it is reviewed and related to Article 1458 of the Civil Code which contains: "The sale and purchase is considered to have taken place between two parties, immediately after these people have reached an agreement on the object and the price, even though the object has not been submitted, nor has the price been paid". The sale and purchase is legal and has occurred, only the rights/collateral have not been controlled and have not been transferred. If viewed from the bank's point of view, the Transfer of Home Ownership Loans under the hand

\footnotetext{
${ }^{7}$ Kadir, Muhammad Abdul. (2000). Hukum Perdata Indonesia, Bandung: PT. Citra Aditya Bakti, p. 23

${ }^{8}$ Badrulzaman, Mariam Darus. (1983). Perjanjian Kredit Bank, Bandung: Alumni, p. 43
} 
from a legal perspective this action is not justified because it will harm third parties for several reasons:

1) The transfer of rights to objects that become bank collateral is prohibited without the knowledge of the bank.

2) Even though the second party continues the installments every month, if the credit is paid off, the certificate (collateral) can only be submitted by the bank to the first party, because the collateral is still in the name of the first party.

3) It could happen close to settlement, the first party (who has actually sold to a third party) then comes to the bank to pay off and take the certificate which is actually the right of a third party.

4) If the first party dies, it is possible that the heirs will still acknowledge that the land and house are their right, even though the third party shows proof of payment receipt. If a lawsuit occurs, the third party will lose because the heirs have stronger legal force.

5) The house sold is still registered as collateral for credit at the bank, so the debtor has no right to transfer it to any party without the knowledge of the bank. Banks have the authority to report debtors to the authorities with accusations of embezzlement as well as to file criminal charges against the debtor who transferred the Home Ownership Credit.

The transfer of ownership of KPR BTN through buying and selling is not prohibited as long as it is carried out in accordance with the procedures established by the BTN. ${ }^{9}$ For the sale and purchase of houses and land for KPRBTN that are carried out under the hands of a notary or Land Deed Making Officer (PPAT), the deed cannot be made because the process is carried out without the approval of BTN as a creditor and is not in accordance with applicable procedures, so the notary may not make the deed as evidence there has been a transfer of ownership of the KPR BTN, in any form of deed ${ }^{10}$.

If the Notary makes a deed related to the transfer of the BTN KPR, the Notary can be sued at a later date by the aggrieved party, especially the buyer and the bank, for having made a deed that is contrary to the law. ${ }^{11}$

According to the author, it will be difficult to get a land certificate from BTN, because the bank will only hand over the certificate to the old debtor. This is even more complicated if the old debtor is not willing to take it or the old debtor is no longer known to exist. So that the legal protection for buyers is very weak.

\footnotetext{
${ }^{9}$ Interview with Sri Subekti, as PPAT/Notary Semarang City, on July 6, 2021.

${ }^{10}$ Ong Argo Victoria, Ade Riusma Ariyana, Devina Arifani. (2020). Code of Ethics and Position of Notary in Indonesia. Sultan Agung Notary Law Review 2 (4), 397-407, http://lppmunissula.com/jurnal.unissula.ac.id/index.php/SANLaR/article/view/13536

11 Interview with Sugeng Budiman, as PPAT/Notary Semarang City, on July 6, 2021.
} 
Based on the research that the author has done at the BTN Branch Office in Semarang City, there are quite a lot of cases of debtor transfer which are carried out under the hands. From the author's research at the Semarang City District Court, there is also a request for approval of the sale and purchase of a BTN KPR house which has already been carried out under the hands of the situation dated November 6, 1985 No. 9842/1985 with an area of $\pm 84 \mathrm{~m}^{2}$ on behalf of $G$ SUGENG WALUYO (Defendant).

Prior to the maturity date of the Defendant's loan repayment period, the house and land were sold privately by the Defendant to the Plaintiff on October 9, 1990 with an agreed price of IDR 1,079,000, - (One million seventy-nine thousand rupiah). The Plaintiff has purchased the house and land, the Plaintiff bears what is the Defendant's obligation, namely to pay the installments of the Home Ownership Credit up to the full amount to the Co-Defendant, but when the Building Rihts Use(HGB) certificate will be reversed to be in the name of the Plaintiff, but by The Defendant was not submitted without the presence of the Defendant, and the Plaintiff has tried to find the Defendant everywhere to be invited to follow up the sale and purchase of the house and land to no avail. so that there is no other way for the Plaintiff than to file a lawsuit against the Defendant. The house and land have been inhabited by the Plaintiff and his family since the sale and purchase with the Defendant was carried out on October 9, 1990 until now.

The panel of judges from the case stated that they granted the Plaintiff's claim entirely with verstek, stated that the sale and purchase under the hands of the house and land with KPR certificate of Building Rihts Use(HGB) No. 1004/Srondol Wetan, known as St. Rasamala III/406, Srondol Wetan Village, Banyumanik District, Semarang City. The Defendant is deemed to have defaulted/broken promise, and sentenced the Co-Defendant (PT BANK TABUNGAN NEGARA (Persero) SEMARANG BRANCH to submit a Building Use Rights certificate) No. $1004 /$ Srondol Wetan and to punish the Defendant to pay the costs arising from this case.

The house that is used as the object of sale and purchase between the plaintiff and the defendant is a KPR BTN as stated in KPRBTN No. 015.1652.0 C 0485 Q. And in the KPR/BTN credit agreement the defendant as a debtor is obliged to pay in monthly installments of IDR 448,800,- (Four hundred forty eight thousand eight hundred rupiah). Legal problems then arose because since the house credit was made over, the defendant's place of residence was unknown either in the country or in the jurisdiction of the Republic of Indonesia, while the defendant had agreed to sell the residence mentioned above and promised to complete the paperwork and so on. 
After the plaintiff has fulfilled all the obligations to pay the mortgage loan installments (KPR-BTN) to the bank, the plaintiff intends to take certificates and other documents regarding the BTN KPR house, but the bank is not willing to submit them, on the grounds that the KPR-BTN credit agreement was made, between the defendant and the bank, not between the plaintiff and the bank and credit documents to resolve this issue must go through a process in court.

\section{Conclusion}

Legal protection for buyers in cases of buying and selling houses and land under the hands is very weak because buying and selling under the hands does not result in the transfer of land rights. So that legally the house and land still belong to the old KPR BTN owner (old debtor). Legal protection for buyers can only be obtained by submitting an application for a determination to the local district court to ratify the buying and selling process that has been carried out under the hands. Meanwhile, for banks as creditors, they have been protected by the Mortgage Agreement and the Mortgage Law, considering that Mortgage gives priority or precedence to the holder (droit de preference) and Mortgage always follows the object guaranteed in the hands of whoever the object is (droit de suites). The legitimacy of buying and selling that aims to take over home ownership loans privately is not binding on third parties. In connection with this, according to law the legal owner of the land and building is owner of the first party so that the transfer of rights must go through/obtain the approval of the first party. This makes it difficult in the future, especially if the owner's whereabouts are known. So for the bank, it cannot be recognized as a sale and purchase. If you have paid the installments, you still cannot take the certificate. The process of transferring to a mortgage, is a novation legal action, namely a process of replacing the old agreement by a new agreement, which causes the old agreement to be deleted, so that what follows is a new agreement with changes to the terms and conditions.

\section{References}

Journals:

[1] Ong Argo Victoria, Ade Riusma Ariyana, Devina Arifani. (2020). Code of Ethics and Position of Notary in Indonesia. Sultan Agung Notary Law $\begin{array}{llll}\text { Review } & 2 & \text { (4), 397-407, http://lppm- }\end{array}$ unissula.com/jurnal.unissula.ac.id/index.php/SANLaR/article/view/13536

[2] Sapi'i. (2016). Pemilihan Pembiayaan KPR (Kredit Pemilikan Rumah) Dengan Akad Murabahah (Studi Kasus Di Bank Muamalat Tbk Cabang 
Pembantu Samarinda Seberang), Al-Tijary Jurnal Ekonomi dan Bisnis Islam, Vol. 2 (No. 1)

[3] Yusuf, Rifki. (2018). Peran Notaris Dalam Penggunaan Akta SKMHT Yang Tidak Diikuti APHT Terhadap Debitor Wanprestasi Terkait Pemberian Fasilitas Kredit Pemilikan Rumah Subsidi (Studi Kasus di Bank Tabungan Negara Pekalongan), Jurnal Akta, Vol 5, (No. 1)

Books:

[1] Badrulzaman, Mariam Darus. (1983). Perjanjian Kredit Bank, Bandung: Alumni

[2] Kadir, Muhammad Abdul. (2000). Hukum Perdata Indonesia, Bandung: PT. Citra Aditya Bakti

Regulation:

[1] Constitution of the Republic of Indonesia 1945

[2] Code of Civil law

[3] Act No. 10 of 1998 concerning Banking Principles

[4] Act No. 4 of 1992 concerning Housing and Settlements

[5] Act No. 4 of 1996 concerning the Mortgage Rights Act (UUHT) Interview:

[1] Interview with Bayu Sulistyo, as the Head of the Semarang City BTN Branch on Semarang, July 6, 2021.

[2] Interview with Sri Subekti, as PPAT/Notary Semarang City, on July 6, 2021.

[3] Interview with Sugeng Budiman, as PPAT/Notary Semarang City, on July 6, 2021.

[4] Interview with Susilowati, as PPAT/Notary Semarang City on Semarang, July 10, 2021.

[5] Interview with Y. Sugianto, as the owner of KPR-BTN in Semarang on Semarang, July 6, 2021.

[6] Turkhon Maulawy, interview, Head of Semarang City BTN Branch, (Semarang, August 14, 2021). 